\title{
CARBON DIOXIDE EMISSIONS IN RETAIL FOOD
}

Radojko Lukić1 , Srđan Lalićn ${ }^{2}$, Azra Sućeska ${ }^{3}$, Aida Hanić ${ }^{4}$, Milica Bugarčić ${ }^{5}$

*Corresponding author E-mail:milica.bugarcic@bba.edu.rs

A R T I C L E I N F O
Review Article
Received: 03 May 2018
Accepted: 10 June 2018
doi:10.5937/ekoPolj1802859L
UDC 622.324.6:[641+339.179]

Keywords:

greenhouse gas emissions, carbon dioxide, $\mathrm{CO} 2$ emission sources, renewable energy sources, sustainable reporting

JEL: I10, L81, M14, M41, Q42, Q56, Q57

\begin{abstract}
A B S T R A C T
The analysis of the effects of applying the concept of sustainable development in retail has been attracting interest recently. In that context we have considered greenhouse gases emission in retail. This is achieved by using modern ecological technology in business - through the whole food value chain. The goal is to achieve the planned reductions of carbon dioxide in retail food, which positively reflects the overall performance of food retailers. This empirical research is mainly based on the analysis of the original sustainable reports officially disclosed by selected food retailers. These reports are now an integral part of the integrated reporting on performance of global food retailers. Having been universally important, harmonized regulations on sustainable retail food reporting are being increasingly applied as a data source for more efficient environmental management. In the future, this will enable the comparative analysis of the carbon dioxide emission of global and other food retailers.
\end{abstract}

(C) 2018 EA. All rights reserved.

1 Radojko Lukić, Full Professor, Faculty of Economics, University of Belgrade, Kamenicka 6, 11000 Belgrade, Republic of Serbia, +381638824829, rlukic@ekof.bg.ac.rs,ORCID ID: 0000-0001-6529-0297

2 Srđan Lalić, Assistant Professor, Faculty of Economics Brcko, University of East Sarajevo, Studentska 11, 76100 Brcko, Bosnia and Herzegovina, +38765647580, srdjan.lalic.efb@ gmail.com, ORCID ID: 0000-0003-1874-8765

3 Azra Sućeska, Assistant professor, Belgrade banking academy, University "Union" in Belgrade, Zmaj Jovina 12, 11000 Belgrade, Republic of Serbia, +38166234304, azra. hanic@bba.edu.rs, ORCID ID: 0000-0001-6971-1706,

4 Aida Hanić, Research Assistant, Institute of Economic Sciences, Zmaj Jovina 12, 11000 Belgrade, Republic of Serbia, +381603502190, aida.hanic@ien.bg.ac.rs, ORCID ID: 00000003-4378-7002

5 Milica Bugarčić, Teaching Assistant, Belgrade banking academy, University "Union” in Belgrade, Zmaj Jovina 12, 11000 Belgrade, Republic of Serbia, +381644641881, milica. bugarcic@bba.edu.rs, ORCID ID: 0000-0002-9327-9965

http://ea.bg.ac.rs 


\section{Introduction}

Significant attention has been recently paid to the analysis of environmental performance in all sectors, including wholesale and retail trade. Within this, greenhouse gases emission $(\mathrm{GHG})$ in retail food is briefly considered. The overall goal of global food retailers is to reduce carbon dioxide emissions through the entire food value chain. The costs of carbon dioxide emission reduction are significant and affect the performance of food retailers.

The subject of research in this paper is the significance and trend of carbon dioxide emissions in retail food. Based on a comparative analysis of the original officially disclosed sustainable reports of global food retailers, the aim of the research is to comprehensively examine the problem of carbon dioxide emissions in retail through the entire food value chain and to take appropriate measures to achieve the target reduction. The effects of this are the improvement of the overall, especially environmentallyfriendly performance of food retailers. The scientific and professional contribution of this work can be reflected in that, because there is scarce literature fully devoted to the issue of carbon dioxide emissions in retail food.

Numerous factors undoubtedly influence carbon dioxide emissions in retail, and these are as follows: type of store, product category, nature of the item itself, sales, location and distance (type of settlement: urban, suburban and rural), carbon policy (Wang et al., 2017), as well as energy sources, type of ventilation and heating of sales and other premises, cooling devices, mode of transport (logistics), waste treatment, and others. Taxation is also a factor in carbon dioxide emissions in all sectors, including retail food (Qin, 2015). Regarding retail formats (types of stores, classical or modern Internet shops) on-line sales have insignificant carbon dioxide emissions and, viewed through a value chain, it occurs only in warehousing, while in distribution and in the store, equals zero, contrary to the other types of stores (Seebauer et al., 2016). Carbon dioxide emissions vary by product category (food and non-food products) and within one product category, by individual items, depending on their nature (Linda, 2014; Sullian 2016; Eriksson, 2017). All in all, the main sources of carbon dioxide emissions in retail are as follows: electricity, transport, ventilation and heating, refrigeration and waste. Effective control of the factors that influence the emission of carbon dioxide can significantly affect the improvement of economic, social and, in particular, environmental performance in retail. For these reasons, it is necessary to know the size and intensity of carbon dioxide emissions in modern retail food, which is the focus of this work.

\section{Materials and methods}

There is a voluminous literature devoted to analyzing the way company's performance is affected by general problems and effects of carbon dioxide emission reduction through the whole (food) chain (Jones, 2005; Martinuzzi, 2011; Kahn, 2014; Congcong, 2016; Li, 2016; Seebauer et al., 2016; Bazan, 2017, Clune, 2017), as well as consumer 
preferences $(\mathrm{Ji}, 2017)$. In other words, it is generally known that carbon dioxide reduction increases the economic performance of companies (Cusshiella, 2017), the profitability of producers and retailers, as well as consumer preferences (Eagle, 2017). In view of the significance of the problem of carbon dioxide emissions, generally speaking, the number of papers dedicated to the specificities and impacts of carbon dioxide emission reduction on the performance of retail companies is modest (Patten, 2014; Makarov, 2015; Riboldazzi, 2016; Sullian, 2016). In Serbian literature this issue is only partially considered in some papers (Lukic, 2011a, b, 2012, 2014, 2016a, b, c, 2017). For that reason, this paper attempts to make thorough analysis of specific issues of carbon dioxide emissions in the retail sector, i.e.retail food, firstly on the example of global retailers from different countries, primarily developed market economies, which, due to the general importance of the matter, publish reports on sustainable development along with regular annual financial reports. This practice of global retailers provides them with more reliable information base for efficient management of carbon dioxide emissions through the whole value chain. This is particularly true for retailers in Serbia whose practice of making the reports on environment and sustainable development publicly available has just begun.

The general research hypothesis in this paper is that the reduction of carbon dioxide emissions positively reflects on overall (integrated, especially environmental) performance of retailers (food). The methodology is primarily based on the comparative analysis of the carbon dioxide emission of global selected food retailers from various comparable developed market economies. The problem of comprehensiveness of the research on carbon dioxide emissions in retail food is that, at the time being, there is no unified system of sustainable (environmental) reporting for all retailers. In addition, many retailers still do not publish their reports, thus providing an incomplete "comparability" of data on carbon dioxide emissions by individual food retailers. Nevertheless, understanding of the importance and trend of carbon dioxide emissions from global retailers (food) is very important in order to manage overall, integrated and, in particular, environmental performance in (concrete) retail (food). Globally, other food retailers will increasingly publish reports on sustainable development (with data oncarbon dioxide emissions). In this way, they will increase its information base for more efficient management of total business, including environmental protection. This may have a positive impact on the gain of the target profit.

The main data sources for the research of the treated problem in this paper are literature, articles, publications, studies, OECD, Eurostat and, in particular, officially disclosed annual financial and sustainable reports of (global) retailers (food). They were processed in such a way that is easy to comprehend the significance and trend of carbon dioxide emission in retail food. 


\section{Results and discussion}

The carbon dioxide emission through the entire food value chain is shown in Table 1.

Table 1. Emissions of carbon dioxide through the life cycle of food after farm

\begin{tabular}{|l|c|c|l|c|l|l|}
\hline $\begin{array}{l}\text { Lifecycle } \\
\text { stage post- } \\
\text { farm gate }\end{array}$ & $\begin{array}{l}\text { Number of GWP } \\
\text { (global warming } \\
\text { potential) values }\end{array}$ & $\begin{array}{l}\text { Median } \\
(\mathbf{k g C O} \\
\mathbf{e q} / \mathbf{k g})\end{array}$ & $\begin{array}{l}\text { Mean } \\
(\mathbf{k g C O} \text {-eq/ } \\
\mathbf{k g})\end{array}$ & Stdev & $\begin{array}{l}\text { Min } \\
(\mathbf{k g C O} \text {-eq/ } / \\
\mathbf{k g})\end{array}$ & $\begin{array}{l}\text { Max } \\
(\mathbf{k g C O} \text {-eq/ } \\
\mathbf{k g})\end{array}$ \\
\hline $\begin{array}{l}\text { Processing } \\
\text { meat }\end{array}$ & 5 & 0,59 & 0,66 & 0,14 & 0,54 & 0,87 \\
\hline $\begin{array}{l}\text { Processing } \\
\text { vegetables }\end{array}$ & 15 & 0,06 & 0,07 & 0,04 & 0,01 & 0,013 \\
\hline Packaging & 8 & 0,05 & 0,06 & 0,06 & 0,01 & 0,21 \\
\hline $\begin{array}{l}\text { Transport to } \\
\text { RDC (Regional } \\
\text { Distribution } \\
\text { Centre }\end{array}$ & 21 & 0,09 & 0,13 & 0,19 & 0,02 & 0,95 \\
\hline Retail & 20 & 0,04 & 0,10 & 0,25 & 0,01 & 1.14 \\
\hline
\end{tabular}

Note: The table is compiled on the basis of various relevant studies.

Source: Clune et al. (2017)

The data in the given table show that, on average, emission of carbon dioxide is higher in the processing of meat than processing of vegetables. It is also higher in transport than in retail, and is the lowest in the packaging phase. This is in line with the nature of the activities concerned.

Different is the carbon dioxide emission of individual retailers (food). This is illustrated by the research results in this paper.

At Wal-Mart (United States of America, Dominant operational format: Hypermarket / Supercenter / Superstore), a great significance is given to reducing carbon dioxide emissions (Table 2.). This is achieved by the following: investing in renewable energy sources, reducing energy demand, improving energy efficiency, improving refrigeration in stores and maximizing the efficiency of the vehicle fleet.

Table 2. Carbon dioxide emission (Scope 1 and 2) and retail area at Wal-Mart, 2005-2014

\begin{tabular}{|l|l|l|l|l|l|l|l|l|l|l|}
\hline & $\mathbf{2 0 0 5}$ & $\mathbf{2 0 0 6}$ & $\mathbf{2 0 0 7}$ & $\mathbf{2 0 0 8}$ & $\mathbf{2 0 0 9}$ & $\mathbf{2 0 1 0}$ & $\mathbf{2 0 1 1}$ & $\mathbf{2 0 1 2}$ & $\mathbf{2 0 1 3}$ & $\mathbf{2 0 1 4}$ \\
\hline $\begin{array}{l}\text { Carbon dioxide } \\
\text { emission } \\
\left(\begin{array}{l}\text { million ton } \\
\left.\mathrm{CO}_{2 \mathrm{e}}\right)\end{array}\right.\end{array}$ & 18,9 & 19,3 & 20,1 & 20,8 & 20,3 & 20,6 & 20,8 & 21,2 & 21,0 & 21,9 \\
\hline $\begin{array}{l}\text { Retail area } \\
\text { (million square } \\
\text { meters) }\end{array}$ & 740 & 805 & 867 & 921 & 952 & 985 & 1,037 & 1,072 & 1,102 & 1,134 \\
\hline
\end{tabular}




\begin{tabular}{|l|l|l|l|l|l|l|l|l|l|l|}
\hline & $\mathbf{2 0 0 5}$ & $\mathbf{2 0 0 6}$ & $\mathbf{2 0 0 7}$ & $\mathbf{2 0 0 8}$ & $\mathbf{2 0 0 9}$ & $\mathbf{2 0 1 0}$ & $\mathbf{2 0 1 1}$ & $\mathbf{2 0 1 2}$ & $\mathbf{2 0 1 3}$ & $\mathbf{2 0 1 4}$ \\
\hline $\begin{array}{l}\text { Carbon dioxide } \\
\text { intensity } \\
(\text { million tons } \\
\mathrm{CO}_{2 \mathrm{e}} / \text { million } \\
\left.\mathrm{m}^{2}\right)^{*}\end{array}$ & 0,025 & 0,024 & 0,023 & 0,022 & 0,021 & 0,021 & 0,020 & 0,020 & 0,019 & 0,019 \\
\hline
\end{tabular}

Note: Calculations performed by the author

Source: Wal-Mart Stores, Inc. 2016 Global Responsibility Report, available at: https://cdn. corporate.walmart.com/9c/73/3f9abcef444397f2c771e081e095/2016-global-responsibilityreport.pdf\#page $=58 \&$ zoom $=$ auto, $-130,628$

In generating greenhouse gas emissions, Wal-Mart participates with the following: electricity supply $69 \%$, refrigeration $18 \%$, fuel transport $5.9 \%$, fuel on the site $7 \%$ and mobilerefrigerators with $0.1 \%$ (Wal-Mart Stores, Inc. 2016 Global Responsibility Report, available at: https://cdn.corporate.walmart.com/9c/73/3f9abcef444397f2c771e081 e 095/2016-global-responsibility-report.pdf\#page=58\&zoom=auto,-130,628. Therefore, the main source of greenhouse gas emissions in Wal-Mart is electricity supply. With the increased application of the ecological operation principles, Wal-Mart reduced carbon dioxide emissions from year to year, which reflects favourably on its overall performance, especially environmental.

In Kroger (United States, Dominant operational format: Hypermarket / Supercenter / Superstore) carbon dioxide emissions amounted to 32.9 (tonnes of $\mathrm{CO}_{2} \mathrm{e} / 1,000 \mathrm{sq}$ $\mathrm{ft}$ ) in 2015 , and 36.3 in 2006 . This means that there was a $9.3 \%$ reduction achieved (2016 Sustainability Report / Kroger, available at: http://sustainability.kroger.com / environment-energy-carbon.html. The effects of this decrease are the improvement of environmental and overall performance in the company Kroger.

At Tesco (United Kingdom, Dominant operational format: Hypermarket / Supercenter / Superstore), as with Wal-Mart, considerable attention is paid to the research and control of carbon dioxide emissions. This positively reflects on its overall performance, including the surrounding ones. , Illustration of the specificity of carbon dioxide emissions measurement at Tesco is shown in Figure 1. 
Figure 1. Tesco’s emission limit

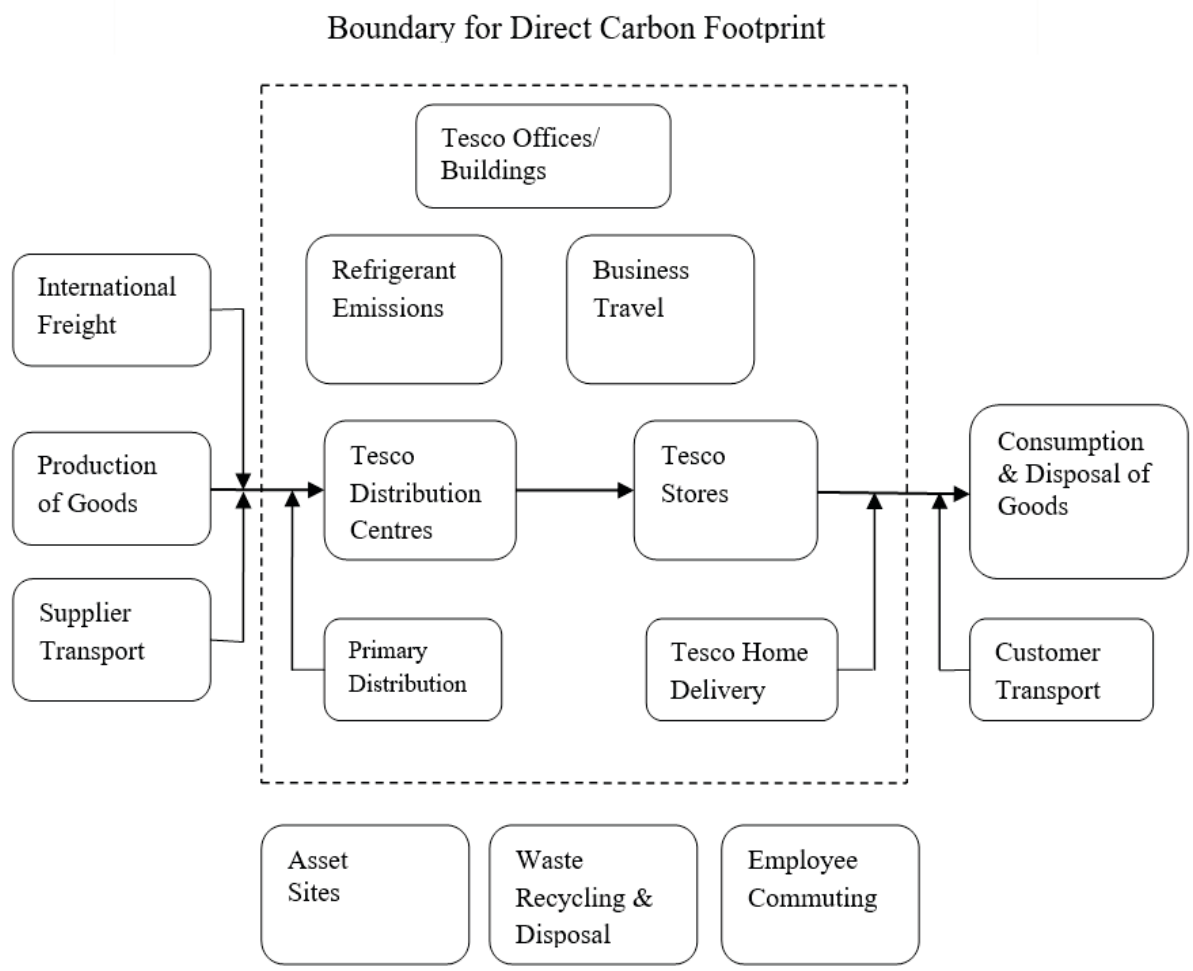

Source: Carbon Footprint 101: A Guide for Food Retailers, available at:https://www. fmi.org/docs/sustainability/carbon-footprint-101-a-guide-for-foodretailers.pdf? $\underline{\text { sfvrsn}=4 \# \text { page }=11 \& \text { zoom }=\text { auto, }-121.85}$

Table 3. and Figure 2. show the greenhouse gas emissions in Tesco.

Table 3. Emission of greenhouse gases in Tesco

\begin{tabular}{|l|c|c|c|}
\hline & \multicolumn{3}{|c|}{ Total ton $\mathbf{C O}_{\mathbf{2 e}}$} \\
\cline { 2 - 4 } & $\mathbf{2 0 1 6 / 1 7}$ & $\mathbf{2 0 1 5 / 1 6}$ & $\begin{array}{c}\text { Base year } \\
\mathbf{2 0 0 6} / \mathbf{0 7}\end{array}$ \\
\hline Scope 1 & $1,236,980$ & $1,301,746$ & $1,345,507$ \\
\hline Scope 2 & & & Not available \\
\hline Market-based method & $1,582,275$ & $2,004,992$ & $2,259,984$ \\
\hline Location-based method & $2,357,245$ & $2,528,323$ & 51,14 \\
\hline $\begin{array}{l}\text { Scope 1 and 2 carbon } \\
\text { dioxide intensity (kgCO } \\
\text { sq. ft of stores and } \\
\text { distributive centres) }\end{array}$ & 22,95 & 26,33 & $1,064,460$ \\
\hline Scope 3 & $1,073,721$ & $1,097,491$ & \\
\hline
\end{tabular}




\begin{tabular}{|l|c|c|c|}
\hline & \multicolumn{3}{|c|}{ Total ton $\mathbf{C O}_{2 \mathrm{e}}$} \\
\cline { 2 - 4 } & $\mathbf{2 0 1 6 / 1 7}$ & $\mathbf{2 0 1 5 / 1 6}$ & $\begin{array}{c}\text { Base year } \\
\mathbf{2 0 0 6 / 0 7}\end{array}$ \\
\hline Total gross emission & $3,892,977$ & $4,404,230$ & $4,669,951$ \\
\hline $\begin{array}{l}\mathrm{CO}_{2 \mathrm{e}} \text { from renewable energy } \\
\text { exported to the grid }\end{array}$ & 1,154 & 1,513 & - \\
\hline Total net emissions & $3,891,822$ & $4,402,717$ & $4,669,951$ \\
\hline $\begin{array}{l}\text { Overall net carbon intensity } \\
\text { (total net emissions } \\
\mathrm{kgCO} \\
\text { distributive centres) }\end{array}$ & 31,69 & 35,06 & 66,23 \\
\hline
\end{tabular}

Source: Tesco PLC Annual Report and Financial Statements 2017, available at: https://www. tescoplc.com/media/392373/68336_tesco_ar_digital_interactive_250417.pdf

The data in the given table show that the intensity of carbon dioxide emissions in Tesco is decreasing from year to year.

Figure 2. Total carbon dioxide (million tonnes of CO2e) in Tesco 2016/2017

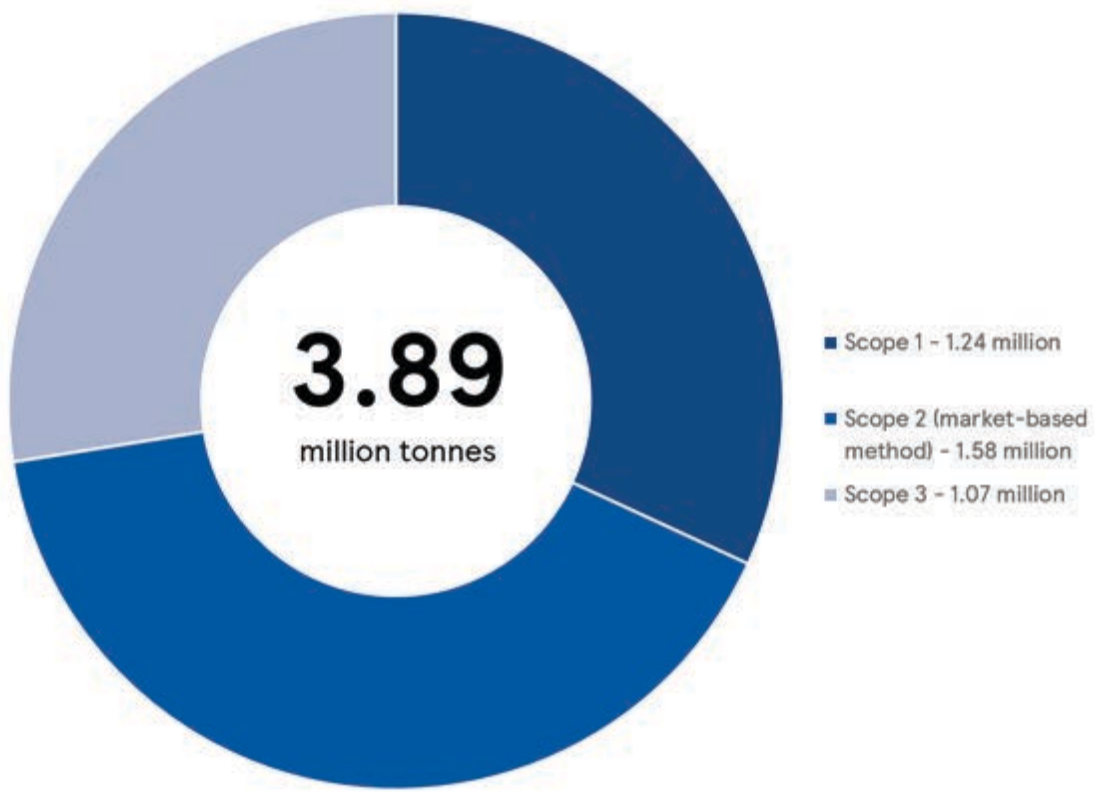

Source: Tesco - Our carbon footprint, available at:https://www.tescoplc.com/tesco-and-society/ sourcing-great-products/reducing-our-impact-on-the-environment/our-carbon-footprint/

Figure 3. shows sources of carbon dioxide emission throughout the value chain, with an emphasis on Tesco's participation in carbon footprint. 
Figure 3. Emissions of carbon dioxide by source in Tesco

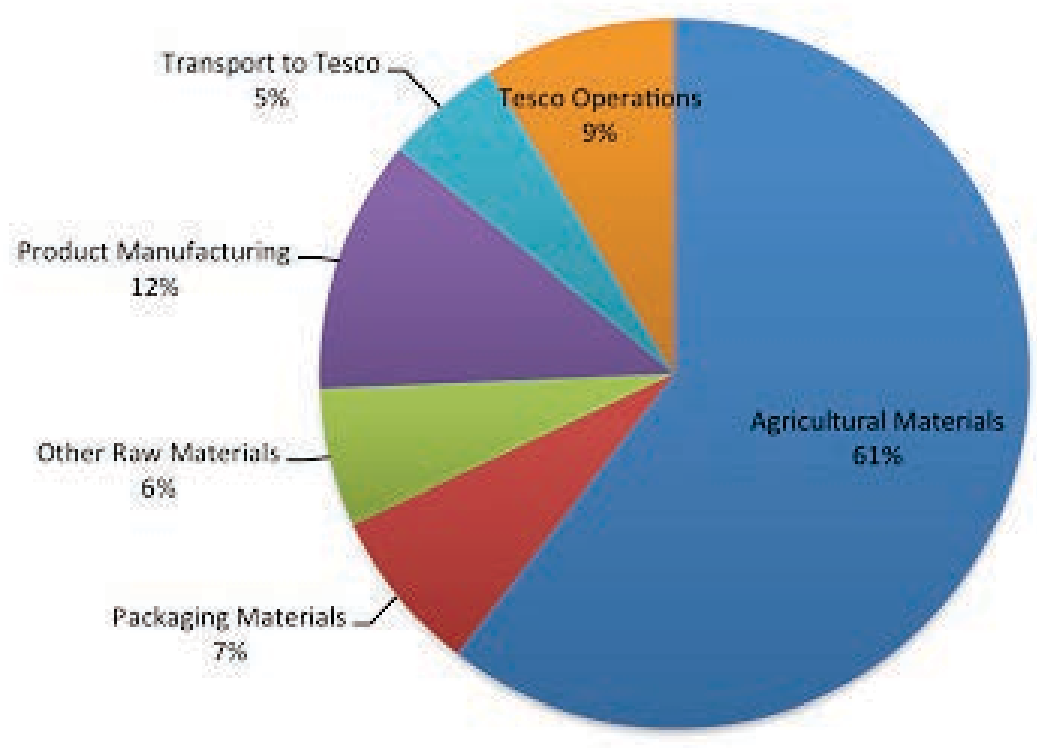

Source: Tesco - Our Carbon Footprint, available at: https://www.tescoplc.com/tesco-andsociety/sourcing-great-products/reducing-our-impact-on-the-environment/our-carbonfootprint/

Therefore, Tesco participated in total emission of carbon dioxide through entire value chain with $9 \%$.

Table 4. shows ecological performances at Tesco.

Table 4. Global ecological performances at Tesco

\begin{tabular}{|l|c|c|c|c|}
\hline & $\mathbf{2 0 1 6 / 1 7}$ & $\mathbf{2 0 1 5 / 1 6}$ & $\mathbf{2 0 1 4 / 1 5}$ & $\mathbf{2 0 1 3 / 1 4}$ \\
\hline Carbon dioxide (million ton $\mathrm{CO}_{2 \mathrm{e}}$ ) & 3,9 & 5,1 & 5,26 & - \\
\hline $\begin{array}{l}\text { Emission of } \mathrm{CO}_{2} \text { reduction (stores and } \\
\text { distributional centres) compared to } \\
2006 / 07\end{array}$ & $40,5 \%$ & $39,5 \%$ & $38,3 \%$ & - \\
\hline $\begin{array}{l}\text { Emission of } \mathrm{CO}_{2} \text { reduction (distribution) } \\
\text { compared to 2011/12 }\end{array}$ & $19,7 \%$ & $17.4 \%$ & $14,47 \%$ & $7,8 \%$ \\
\hline Direct water consumption (million $\mathrm{m}^{3}$ ) & 23,5 & 25,5 & 32,6 & 32,9 \\
\hline $\begin{array}{l}\text { Waste percentage (food and non-food) } \\
\text { which is recycled, used again or turn } \\
\text { into energy }\end{array}$ & $93 \%$ & $88 \%$ & $84 \%$ & $86 \%$ \\
\hline
\end{tabular}

Source: Reducing our impact on the environment, available at: https://www.tescoplc.com / tesco-and-society/sourcing-great-products/reducing-our-impact-on-the-environment/ 
Tesco has tendency to improve ecological performances (carbon dioxide emission reduction, direct water consumption reduction and waste treatment improvement). This reflects favourably on its market, economic and financial performances.

Due to the increasing importance, special attention is paid to carbon dioxide emissions in Marks \& Spencer (M \& S) (United Kingdom, Dominant Operating Format: Department Store), as shown in Table 5.

Table 5. Emission of carbon dioxide in Marks \& Spencer

\begin{tabular}{|c|c|c|c|c|c|}
\hline & $\begin{array}{c}\text { Plan A } \\
\text { baseline } \\
2006 / 7 \\
(000 \text { tCO } \\
\end{array}$ & 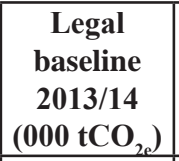 & $\begin{array}{c}\text { Last year } \\
2014 / 15 \\
\left(000 \text { tCO }_{2 \mathrm{e}}\right)\end{array}$ & $\begin{array}{c}2015 / 16 \\
000 \text { tCO }_{2 \mathrm{e}}\end{array}$ & $\begin{array}{c}\text { Achievement } \\
\text { in relation to } \\
2006 / 7\end{array}$ \\
\hline $\begin{array}{l}\text { Total gross/location- } \\
\text { based emission } \mathrm{CO}_{2 \mathrm{e}}\end{array}$ & 732 & 567 & 592 & 566 & $-23 \%$ \\
\hline $\begin{array}{l}\text { Total carbon intensity } \\
\text { measure (per } 1000 \mathrm{sq} \text {. } \\
\mathrm{ft} \text { of sales floor (ton } \\
\mathrm{CO}_{2 \mathrm{e}} / 1,000 \mathrm{sq} . \mathrm{ft} \text { ) }\end{array}$ & 46 & 30 & 30 & 29 & $-47 \%$ \\
\hline
\end{tabular}

Source: M \& S Plan Report 2016, available at: http://annualreport.marksandspencer.com /M\&S_PlanA_Report_2016.pdf.

At Marks \& Spencer, a decrease in carbon dioxide emissions was recorded in 2014/15 in relation to 2006/7. Reduction was achieved by improving energy efficiency using the so-called "green energy" through the whole value chain.

In 2015, Carrefour (France, Dominant operational format: Hypermarket/Supercenter/ Superstore) emitted 3.61 million tonnes of $\mathrm{CO}_{2}$ e. In 2015, carbon dioxide emissions were reduced by $29.7 \%$ compared to 2010 . The aim is to achieve a reduction in carbon dioxide emissions by $40 \%$ until 2025 and 70\% until 2050 (Unique and Multiple/2015 Annual Activity and Responsible Commitment Report, available at: http://www. carrefour.com/sites/default/files/carrefour_2015_annual_activity_and_responsible_ commitment_report.pdf. This will have a positive impact on Carrefour's environmental and overall performance.

Aldi (Germany, Dominant operational format: Discount Store) also publishes reports on sustainable development, in which special attention is paid to the emission of carbon dioxide. Table 6. shows the greenhouse gas emissions at Aldi.

Table 6. Greenhouse gases emission in Aldi (tons CO2e)

\begin{tabular}{|l|c|c|}
\hline & $\mathbf{2 0 1 4}$ & $\mathbf{2 0 1 5}$ \\
\hline Scope 1 & 284,831 & 312,940 \\
\hline Scope 2 & 369,961 & 567,424 \\
\hline Total & 654,792 & 680,364 \\
\hline
\end{tabular}

Source: Aldi-Sustainability Report 2015, available at: https:/www.cr-aldinord.com/2015/wpcontent/uploads/sites/2/2016/04/ALDI_North_Group_NHB_Sustainability_Report_2015.pdf. 
At Aldi, greenhouse gases emissions by sectors (in percent) in 2015 were as follows: electricity $53.1 \%$, cooling equipment $20.0 \%$, heating energy $14.3 \%$ and logistics $12.6 \%$ (Aldi-Sustainability Report 2015,available at:https://www.cr-aldinord.com/2015/ wpcontent/uploads/sites/2/2016/04/ALDI_North_Group_NHB_Sustainability_ Report_2015.pdf.)

In order to reduce greenhouse gas emissions, special attention is paid to the use of energy from renewable sources (LED lamps).

At Ahold (Germany, Dominant operational format: Supermarket), considerable attention is paid to the reduction of carbon dioxide emissions. This is shown in Table 7.

Table 7. Carbon dioxide emission at Ahold

\begin{tabular}{|c|c|c|c|c|c|c|c|c|}
\hline & 2008 & 2009 & 2010 & 2011 & 2012 & 2013 & 2014 & 2015 \\
\hline $\begin{array}{l}\text { Carbon dioxide } \\
\text { emissions } \\
\text { (thousand tons) }\end{array}$ & & & & 2,176 & 2,106 & 2,107 & 2,090 & 2,019 \\
\hline $\begin{array}{l}\text { Carbon dioxide } \\
\text { emissions (kg } \\
\mathrm{CO}_{2} / \mathrm{m}^{2} \text { sales } \\
\text { area) }\end{array}$ & 567 & 574 & 543 & 507 & 480 & 473 & 465 & 420 \\
\hline \multicolumn{9}{|l|}{ Sources (\%) } \\
\hline Electricity & & & & & & & & $49 \%$ \\
\hline $\begin{array}{l}\text { Refrigerant } \\
\text { appliances }\end{array}$ & & & & & & & & $29 \%$ \\
\hline Fuel & & & & & & & & $12 \%$ \\
\hline Gas & & & & & & & & $10 \%$ \\
\hline
\end{tabular}

Source: Ahold - Responsible Retailing Report 2015, available at: https://www.aholddelhaiz e.com/media/1934/ahold-responsible-retailing-report-2015.pdf

Carbon dioxide emissions at Ahold has been decreasing. Since 2016, Ahold has been operating under the name of Ahold Delhaize., Table 8. shows data on carbon dioxide emissions for Ahold Delhaize (Belgium, Dominant operational format: Supermarket) in 2016. 
Table 8. Carbon dioxide emission at Ahold Delhaize

\begin{tabular}{|l|c|c|}
\hline & 2016 Actuals & 2020 Target \\
\hline $\begin{array}{l}\text { \% reduction in } \mathrm{CO}_{2} \text { equivalent emissions per } \mathrm{m}^{2} \text { of } \\
\text { sales area (from } 2008 \text { baseline) }\end{array}$ & $-22 \%$ & $-30 \%$ \\
\hline $\begin{array}{l}\text { Total } \mathrm{CO}_{2} \text { equivalent emissions per } \mathrm{m}^{2} \text { of sales area }- \\
\text { location-based approach }\end{array}$ & 496 & $\mathrm{n} / \mathrm{a}$ \\
\hline $\begin{array}{l}\text { Total } \mathrm{CO}_{2} \text { equivalent emissions (thousand tonnes) } \\
\text { location-based approach }\end{array}$ & 4,505 & $\mathrm{n} / \mathrm{a}$ \\
\hline $\begin{array}{l}\text { Total } \mathrm{Scope} 1 \mathrm{CO}_{2} \text { equivalent emissions (thousand } \\
\text { tonnes) - location-based approach }\end{array}$ & 1,940 & $\mathrm{n} / \mathrm{a}$ \\
\hline $\begin{array}{l}\text { Total } \mathrm{Scope} 2 \mathrm{CO}_{2} \text { equivalent emissions (thousand } \\
\text { tonnes) - location-based approach }\end{array}$ & 2,420 & $\mathrm{n} / \mathrm{a}$ \\
\hline $\begin{array}{l}\text { Total Scope } 3 \mathrm{CO}_{2} \text { equivalent emissions (thousand } \\
\text { tonnes) - location-based approach }\end{array}$ & 144 & $\mathrm{n} / \mathrm{a}$ \\
\hline Offset $\mathrm{CO}_{2}$ equivalent emissions (thousand tonnes) & 241 & $\mathrm{n} / \mathrm{a}$ \\
\hline $\begin{array}{l}\text { Avoided grid electricity } \mathrm{CO}_{2} \text { emissions (thousand } \\
\text { tonnes) }\end{array}$ & 31 & $\mathrm{n} / \mathrm{a}$ \\
\hline
\end{tabular}

Source: Ahold Delhaize Supplementary report on Sustainable Retailing performance 2016, available at: https://www.aholddelhaize.com/media/3984/supplementary-report-on-sustainabl e-retailing-performance-2016.pdf.

Significant reduction in carbon dioxide emissions by 2020 (30\%) is expected at Ahold Delhaize. This will be achieved by using so-called "green energy" in business operations. Sources of carbon dioxide emissions were the following: electricity $60 \%$, cooling devices 31\% and transport 9\% (Ahold Delhaize Supplementary Report on Sustainable Retailing performance 2016, available at: https://www.aholddelhaize.com/ media/3 984/supplementary-report-on-sustainable-retailing-performance-2016.pdf. Delhaize Serbia is also part of Ahold Delhaize which employs the same sustainable development strategy and environment reporting.

In the Fast Retailing (Japan, Dominant Operating Format: Apparel/Footwear Specialty), exceptional attention is paid to the issue of carbon dioxide emission reduction. Figure 4. shows carbon dioxide emissions through the entire value chain in Fast Retailing. 
Figure 4. Sustainable reporting - Carbon dioxide emission through value chain in Fast Retailing
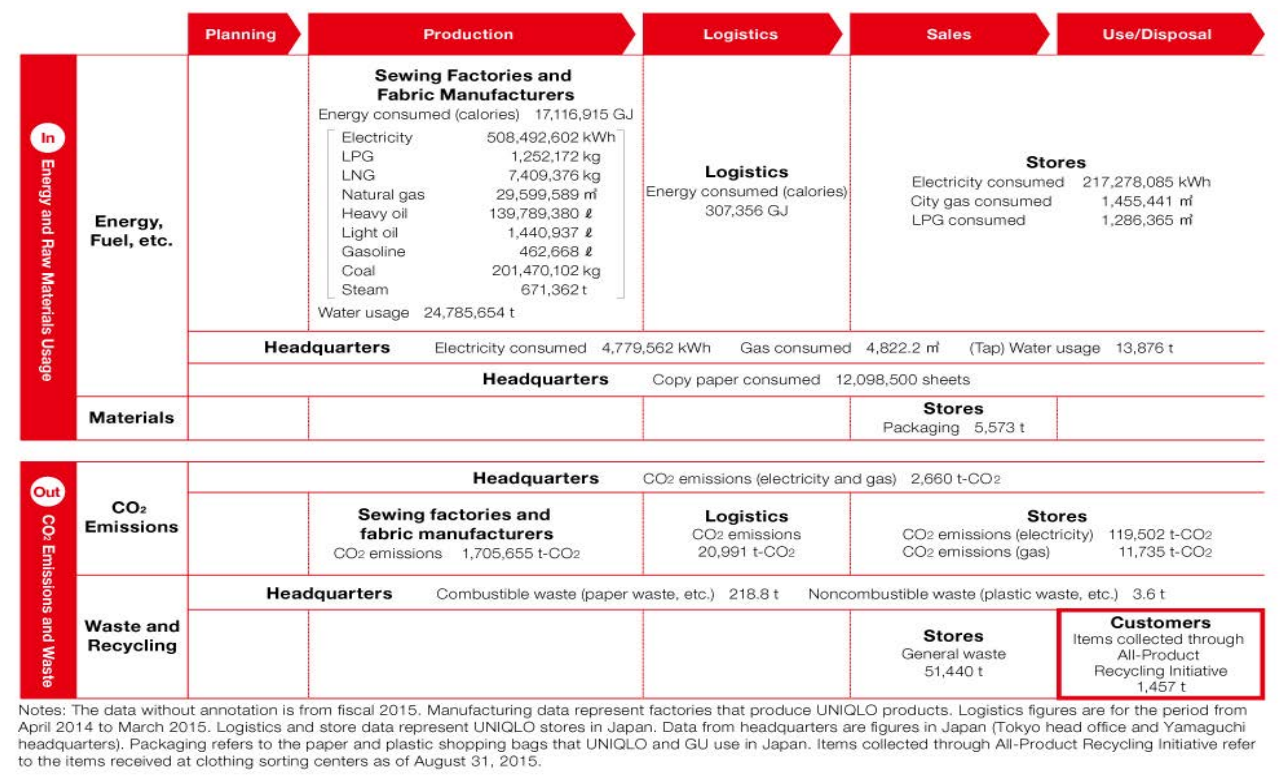

Source: Fast Retailing - Sustainability Report, available at: http://www.fastretailing. com/eng/ sustainability/environment/co2_popup.html

In 2016, at Fast Retailing, carbon dioxide emissions amounted to 2,917,069 $\left(\mathrm{tCO}_{2 \mathrm{e}}\right)$. In logistics it was $17,707\left(\mathrm{tCO}_{2 \mathrm{e}}\right)$. Table 9. presents carbon dioxide emission $\left(\mathrm{tCO}_{2 \mathrm{e}}\right)$ in stores and management offices by sources (generators) at Fast Retailing for 2016.

Table 9. Carbon dioxide emission in stores and management according to sources (generators) at Fast Retailing for 2016 (tCO2e)

\begin{tabular}{|l|r|}
\hline Store gas & 11,436 \\
\hline HQ gas & 38 \\
\hline Total & 11,474 \\
Scope 1 & 123,932 \\
\hline Store electricity & 2,466 \\
\hline HQ electricity & 126,398 \\
\hline $\begin{array}{l}\text { Total } \\
\text { Scope 2 }\end{array}$ & \\
\hline
\end{tabular}

Source: Fast Retailing - Sustainability Report 2017, available at: http:// www.fastretai ling.com/eng/sustainability/report/pdf/sustainability2017 en.pdf\#page $=1 \&$ pagemode $=$ thumbs\&zoom $=80$

FastRetailingplanstoreducecarbondioxideemissionsinstoresby $10 \%$ by 2020 (FastRetailing - Sustainability Report 2017, available at: http://www.fastretailing.com/eng/sustainability/ report/pdf/sustainability2017_en.pdf\#page $=1 \&$ pagemode $=$ thumbs\&zoom $=80.1$ 


\section{Conclusion}

A growing number of retailers (food) in the world have been publishing reports on sustainable development. By their reputation, and because of its importance, other retailers will certainly tend to publish these reports in the future. It provides the basis for a comparative analysis of environmental performance in retail food from various aspects. In this report, special significance is given to trend of greenhouse gas emissions, in particular, carbon dioxide.

Carbon dioxide emissions in trade, in total and by sectors, vary by country. They are significantly higher in China than in Europe or the European Union. Likewise, carbon dioxide emissions are significantly higher in trade of France, Germany and Great Britain than in Greece, Croatia, Turkey and Serbia. Carbon dioxide emissions are higher in Croatian trade than in Serbian. These differences are due to the application of various ecological measures in business.

Carbon dioxide emissions differ in individual stages of the product life cycle, retail companies and product categories. Carbon dioxide emission generators in retail companies are as follows: electricity, transport, ventilation, heating and cooking, refrigeration, and waste. The goal of all retailers is to take appropriate measures, primarily ecological, to reach a planned reduction of carbon dioxide emissions in the future. Among other things, this is achieved with the increasing use of electricity from renewable sources (so-called "green energy"), by using modern ventilation, heating and cooking systems, refrigeration units, green logistics (ecological vehicles) and more efficient waste treatment. The effect of this is to improve the overall performance of retail companies (food), especially environmental.

\section{Conflict of interests}

The authors declare no conflict of interest.

\section{References}

1. Ali, Y., Ciaschini, M., Socci, C., Pretaroli, R., \& Severini, F. (2017). An analysis of $\mathrm{CO}_{2}$ emissions in Italy through the Macro Multiplier (MM) approach. Journal of Cleaner Production, 149, 238-250. https://doi.org/10.1016/j. jclepro.2017.02.094

2. Bazan, E., Jaber, M. Y., \& Zanoni, S. (2017). Carbon emissions and energy effects on a two-level manufacturer-retailer closed-loop supply chain model with remanufacturing subject to different coordination mechanisms. International Journal of Production Economics, 183, 394-408. https://doi.org/10.1016/j. ijpe.2016.07.009 
3. Chatellier-Lorentzen, D., \& Sheinbaum-Parado, C. (2017). Assessing the Impacts of Final Demand on $\mathrm{CO}_{2-\mathrm{eq}}$ Emissions in the Mexican Economy: An Input-Output Analysis. Energy and Power Engineering, 9, 40-54. https://doi. org/10.4236/epe.2017.91004

4. Clune, C., Crossin, E., \& Verghese, K. (2017). Systematic review of greenhouse gas emissions for different fresh food categories. Journal of Cleaner Production, 140 (2), 766-783. 10.1016/j.jclepro.2016.04.082

5. Cucchiella, F., Gastaldi, M., \& Miliacca, M. (2017). The management of greenhouse gas emissions and effects on firm performance. Journal of Cleaner production, 167, 1387-1400. https://doi.org/10.1016/ j.jclepro.2017.02.170

6. Eriksson, M., \& Spångberg, J. (2017). Carbon footprint and energy use of food waste management options for fresh fruit and vegetables from supermarkets. Waste Management, 60, 786-799. https://doi.org/10.1016/ j.wasman.2017.01.008

7. Igl, J., \& Keller, F. (2017). Exploring greenhouse gas reduction opportunities for retailers in Fast Moving Consumer goods distribution networks. Transportation research Part D: Transport and Environment, 50, 55-69. https:// doi.org/10.1016/j.trd.2016.10.008

8. Ji, J., Zhang, Z., \& Yang, L. (2017). Carbon emission reduction decisions in the retail-/dual-channel supply chain with consumers preference. JournalofCleaner Production, 141, 852-867. https://doi.org/10.1016/ j.jclepro.2016.09.135

9. Jones, P., Comfort, D., Hiller, D., \& Eastwood, I. (2005). Retailers and Sustainable development in the UK. International Journal of Retail \& Distribution Management, 33(3), 207-214. https://doi.org/10.1108/09590550510588370

10. Kahn, M. E., \& Kok, N. (2014). Big-Box retailers and urban Carbon emissions: The case of Wal-Mart. NBER Working Papers, 19912, 1-22. https//doi. org/10.3386/w19912

11. Kleemann, L., \& Murphy-Bokern, D. (2014). Reducing greenhouse gas emissions in the food sector: Effects of corporate responsibility. Kiel Working Paper, 1967, 1-39.

12. Li, F., Schwarz; L., \& Haasis, H.D. (2016). A framework and risk analysis for supply chain emission trading. Journal Logistics Research, 9:10, 1-10. https:// doi.org/10.1007/s12159-016-0135-x

13. Lü, C., \& Long, X. (2016). Simulation Research on Supply Chain Carbon Emission Model With SD. Management Science and Engineering, 10(4), 8799. http://dx.doi.org/10.3968/n

14. Lukić, R. (2011). Evaluation of business performance in retail. Center for publishing at the Faculty of Economics, Belgrade. [in serbian: Лукић, P. (2011). Евалуација пословних перформанси у малопродаји]. 
15. Lukić, R. (2012). Sustainable Development of Retail in Serbia. Review of International Comparative Management, 13(4), 574-586.

16. Lukić, R. (2013). Sustainable Cost Management in Retail. Review of International Comparative Management, 14(2), 268-280.

17. Lukić, R., Vojteski-Kljenak, D., \& Jovančević D. (2014). Retail food waste management. Management Research and Practice, 6(4),23-39.

18. Lukić, R. (2016). The impact of energy efficiency on performance in service sector. Economic and Environmental Studies, 16(2), 169-190.

19. Lukić, R. (2016). Analysis of energy costs in retail trade. Management Research and Practice, 8(4), 5-28.

20. Lukić, R., \& Lalić, S. (2016). Energy Efficiency Food Retailers, VII International Agriculture Symposium “Agrosym 2016"Proceedings, University of East Sarajevo and Faculty of Agriculture, Jahorina, 2710-2717.

21. Lukić, R. (2017). Accounting for commercial enterprises. Center for publishing at the Faculty of Economics, Belgrade. [in serbian: Лукић, Р. (2017). Рачуноводство трговинских предузећа].

22. Makarov, I. A., \& Sokolova, A. K. (2015). Carbon emissions embodied in Russia's trade. FIW Working paper, 149, 1-33.

23. Martinuzzi, A., Kudlak, R., Faber, C., \& Wiman, A. (2011). CSR Activities and Impacts of the Retail Sector. RIMAS Working Papers, 4/2011, 1-31.

24. Patten, D. M., \& Zhao, N. (2014). Standalone reporting by U.S. retail companies. Accounting Forum, 38(2), 132-144. https://doi.org/10.1016/ j.accfor.2014.01.002

25. Riboldazzi, S. (2016). Corporate Governance and Sustainability In Italian Large-Scale Retail Companies. European Scientific Journal, 12(16), 1-23. https://dx.doi.org/10.19044/esj.2016.v12n16p1

26. Qin, J., Bai, X., \& Xia, L. (2015). Sustainable Trade Credit and replenishment policies under the Cap-And-Trade and Carbon Tax Regulations. Sustainability, 7(12), 16340-16361. https://dx.doi.org/ 10.3390/su71215818

27. Schönberger, H., Martos, J.L.G., \& Styles, D. (2013). Best Environmental Management Practice in the Retail Trade Sector. JRC Scientific and policy Reports EUR 25998 EN.

28. Seebauer, S., Kulmer, V., Bruckner, M., \& Winkler, E. (2016). Carbon emissions of retail channels: the limits of available policy instruments to achieve absolute reductions. Journal of Cleaner Production, 132, 192-203. https://doi. org/10.1016/j.jclepro.2015.02.028

29. Solilová, V., \& Nerudová, D. (2015). Evaluation of Greenhouse Gas Emissions and Related Aspects: Case of the Czech Republic. Acta Universitatis Agriculturae et Silviculturae Mendelianae Brunensis, 63, 281-292. http:// dx.doi.org/10.11118/actaun201563010281 
30. Sullian, R., \& Gouldson, A. (2016). Comparing the Climate Change Actions, Targets and Performance of UK and US Retailers. Corporate Social Responsibility and Environmental Management, 23(3), 129-136. https://doi. org/10.1002/csr.1364

31. Wang, M., Gündüz, H.I., Herty, M., \& Zhao, L. (2017). Quantity and location decision of fresh food distribution centres for a supermarket chain under carbon policies. 50th Annual Hawaii International Conference on System Sciences Proceedings, Hawaii, 1361-1370.

32. Zhang, G., Liu, M., \& Gao, X. (2014). Dynamic Characteristic Analysis of Indirect Carbon Emissions Caused by Chinese Urban and Rural Residential Consumption Based on Time Series Input-Output Tables from 2002 to 2011. Mathematical Problems in Engineering, 2014, 1-11. http://dx.doi. org/10.1155/2014/297637

33. Zheng, H., Fang, Q., Wang, C., Wang, H., \& Ren, R. (2017). China's Carbon Footprint Based on Input-Output Table Series: 1992-2020. Sustainability, 9(3), 1-17. https://doi.org/10.3390/su9030387 